\title{
Effectiveness of a community-based SGBV prevention model in emergency settings in Uganda: Testing the 'Zero Tolerance Village Alliance' intervention
}

\author{
Chi-Chi Undie \\ Population Council \\ Harriet Birungi \\ Population Council \\ Francis Obare \\ Population Council \\ George Odwe \\ Population Council \\ Jane Harriet Namwebya \\ Population Council \\ Follow this and additional works at: https://knowledgecommons.popcouncil.org/departments_sbsr-rh

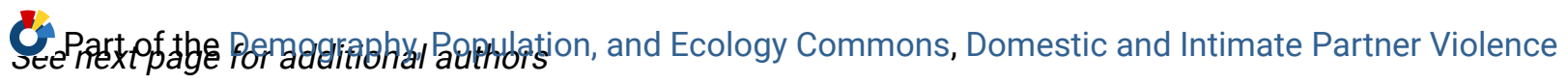 \\ Commons, Family, Life Course, and Society Commons, International Public Health Commons, Maternal \\ and Child Health Commons, and the Women's Health Commons
}

How does access to this work benefit you? Let us know!

\section{Recommended Citation}

Undie, Chi-Chi, Harriet Birungi, Francis Obare, George Odwe, Jane Harriet Namwebya, Paul Orikushaba, Prosmolly Ayebale, William Onen, Fiona Nicholson, Rachel Chisinga-Francis, Peter Netshabako, Anne Katahoire, David Apollo Kazungu, Darlson Kusasira, Zahra Mirghani, and Joanina Karugaba. 2016.

"Effectiveness of a community-based SGBV prevention model in emergency settings in Uganda: Testing the 'Zero Tolerance Village Alliance' intervention." Nairobi: Population Council. 


\section{Authors}

Chi-Chi Undie, Harriet Birungi, Francis Obare, George Odwe, Jane Harriet Namwebya, Paul Orikushaba, Prosmolly Ayebale, William Onen, Fiona Nicholson, Rachel Chisinga-Francis, Peter Netshabako, Anne Katahoire, David Apollo Kazungu, Darlson Kusasira, Zahra Mirghani, and Joanina Karugaba 


\section{EFFECTIVENESS OF A COMMUNITY-BASED SGBV PREVENTION MODEL IN EMERGENCY SETIINGS IN UGANDA:}

\section{Testing the 'Zero Tolerance Village Alliance'}

Intervention

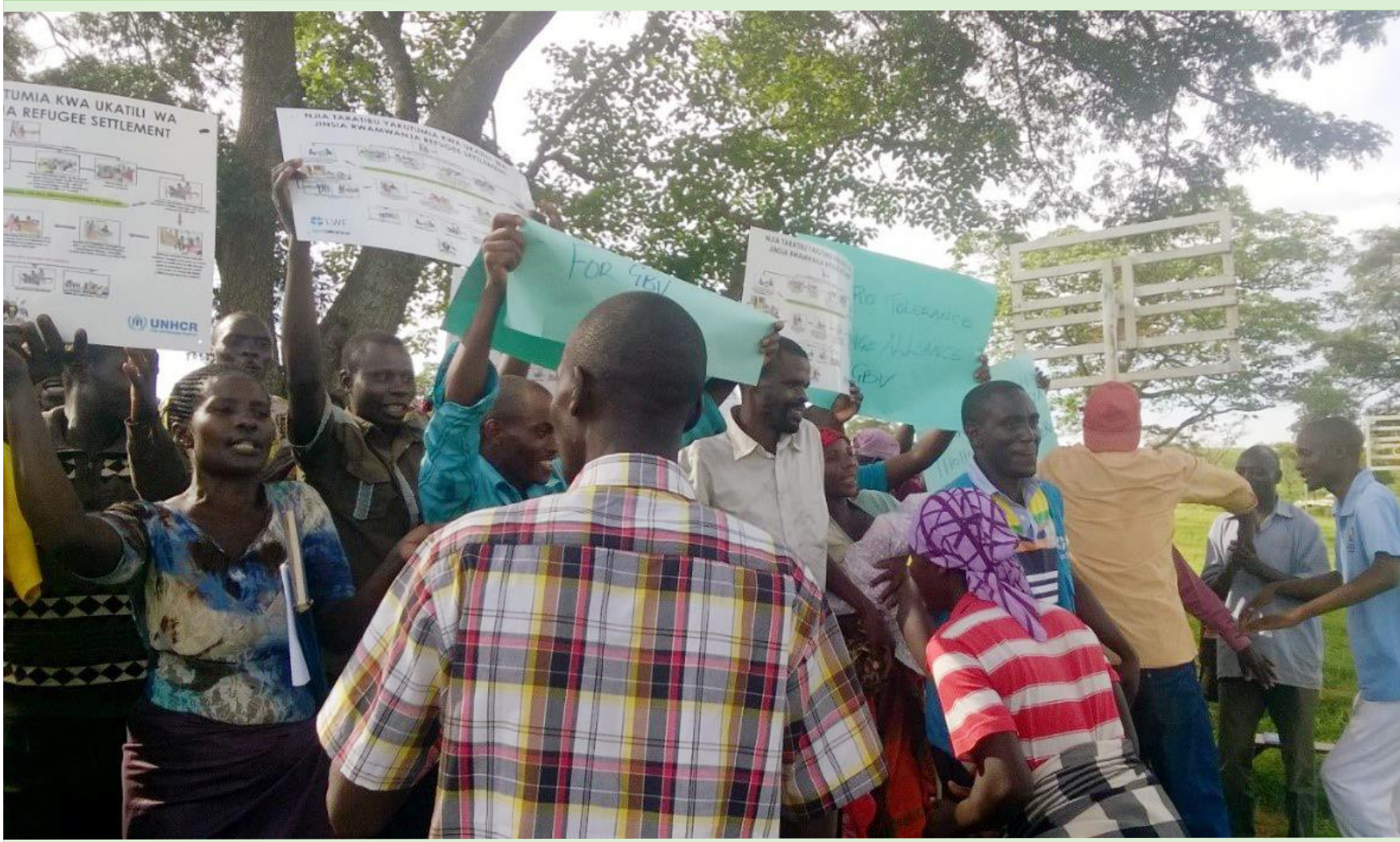

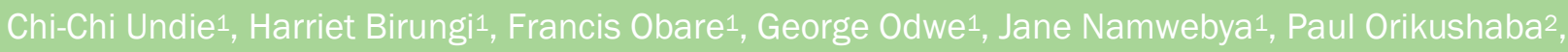
Prosmolly Ayebale², William Onen², Fiona Nicholson ${ }^{3}$, Rachel Chisinga-Francis ${ }^{3}$, Peter Netshabako3, Anne Katahoire ${ }^{4}$, David Apollo Kazungu ${ }^{5}$, Darlson Kusasira, ${ }^{5}$ Zahra Mirghani, ${ }^{6}$ Joanina Karugaba ${ }^{6}$

Population Council1; Lutheran World Federation2; Thohoyandou Victim Empowerment Programme ${ }^{3}$; Child Health \& Development Centre ${ }^{4}$; Refugees Department, Office of the Prime Minister, Uganda ${ }^{5}$ UNHCR Regional Services Centre ${ }^{6}$ 
The Population Council confronts critical health and development issues-from stopping the spread of HIV to improving reproductive health and ensuring that young people lead full and productive lives. Through biomedical, social science, and public health research in 50 countries, we work with our partners to deliver solutions that lead to more effective policies, programs, and technologies that improve lives around the world. Established in 1952 and headquartered in New York, the Council is a nongovernmental, nonprofit organization governed by an international board of trustees.

Population Council

P.O Box 17643

Nairobi, 00500

Nairobi

Tel: +254 202713480 - 3

Fax: +254202713479

email: info.pcnairobi@popcouncil.org

popcouncil.org

Suggested citation: Undie C., Birungi H., Obare F., Odwe G., Namwebya J., Orikushaba P., Ayebale P., Onen, W., Nicholson F., Francis R. C., Netshabako P., Katahoire A., Kazungu D. A., L., Kusasira D., Mirghani Z., Karugaba J. 2016. "Effectiveness of a Community-Based SGBV Prevention Model in Emergency Settings in Uganda: Testing the 'Zero Tolerance Village Alliance' Intervention." Nairobi, Kenya: Population Council.

Cover photo credit: Fiona Nicholson

@2016 The Population Council Inc.
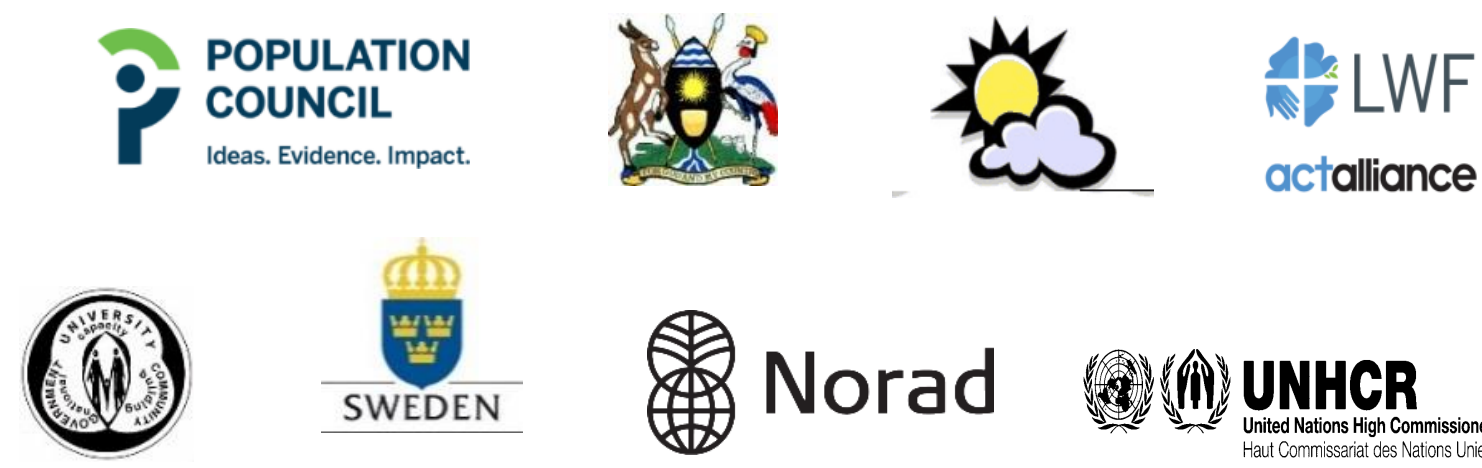

(4) UNHCR 


\section{Table of contents}

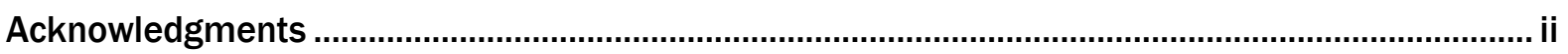

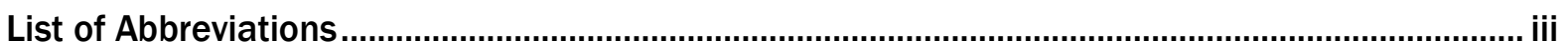

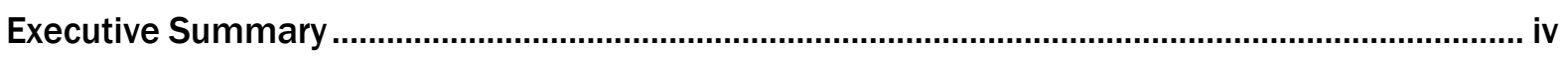

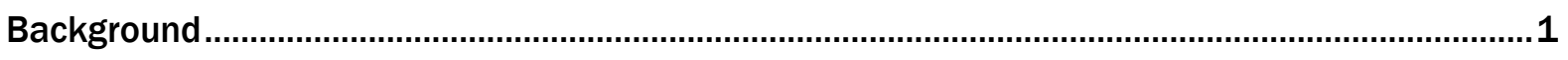

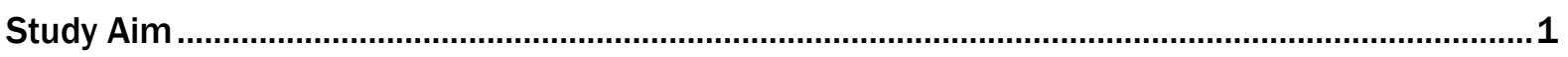

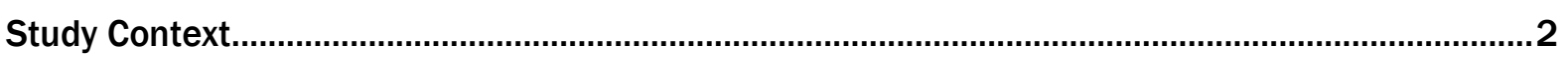

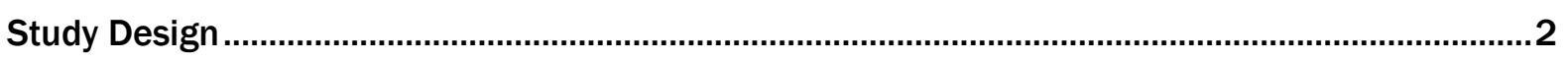

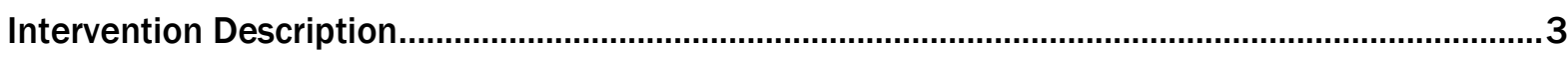

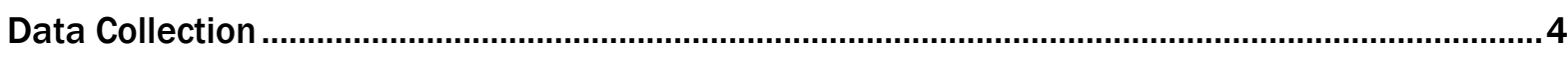

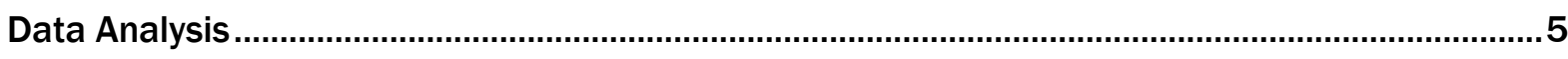

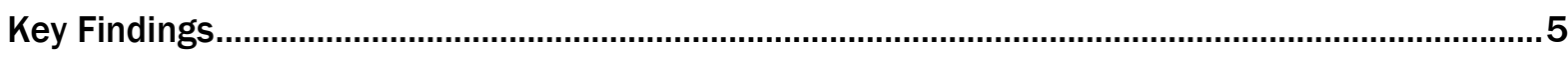

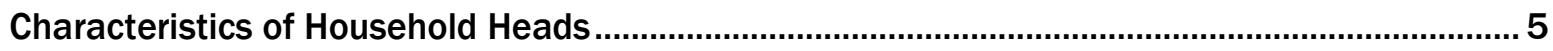

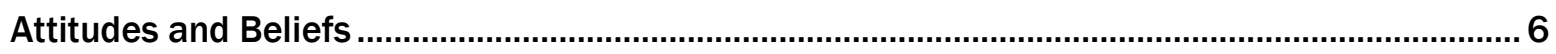

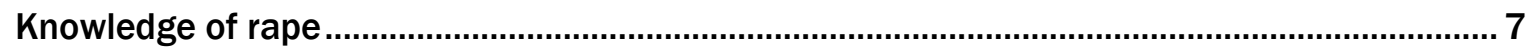

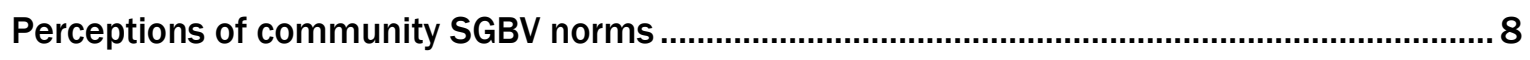

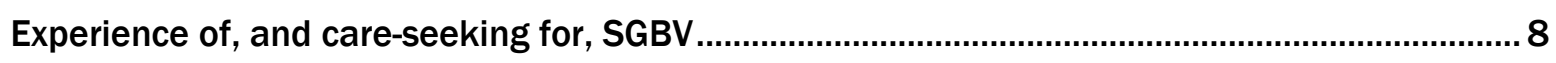

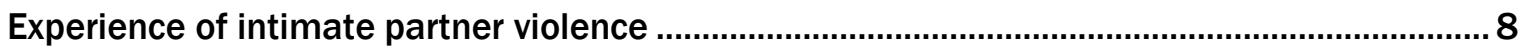

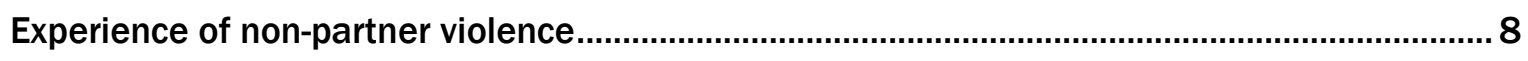

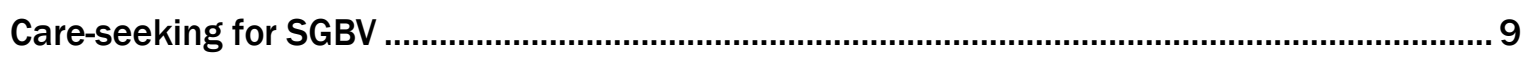

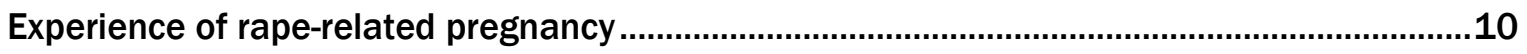

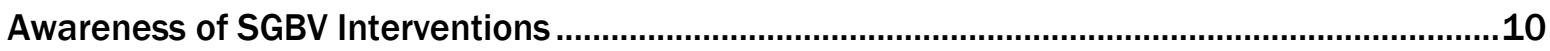

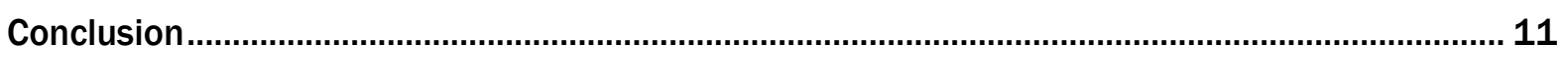

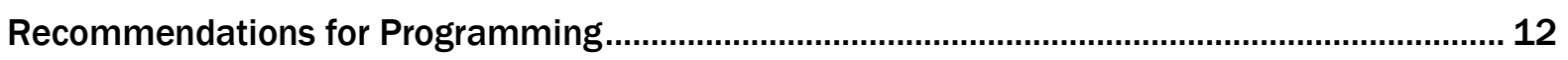




\section{Acknowledgments}

We gratefully acknowledge financial support from the MacArthur Foundation and from the Regional Team for Sexual and Reproductive Health and Rights, Swedish Embassy, Lusaka, Zambia.

We deeply value our partnership with the UNHCR Regional Services Centre in Nairobi, Kenya; the UNHCR Country Office in Kampala, Uganda; the UNHCR Field Offices in Mbarara and Rwamwanja, Uganda; and the Refugees Deparment, Office of the Prime Minister, Uganda. We particularly thank Patterson Njogu, Elsa Bokhre, Andrew Mbogori, Armin Hoso, David Mugenyi, Gershom Golola, and Julian Ateme.

This project received various forms of continuous and valued support from the following staff members of the Population Council: Brian Mdawida, Joyce Ombeva, and Janet Munyasya. Data collection was supported by four dedicated research assistants whose efforts we appreciate: Rosemary Maeri, Wesley Onsongo, Hellen Murugi, and Tom Saria.

To the people of Rwamwanja Settlement: Thank you for sharing your experiences with us. 


\section{List of Abbreviations}

DRC Democratic Republic of Congo

IEC Information, Education, and Communication

IPV Intimate Partner Violence

LWF Lutheran World Federation

SGBV Sexual and Gender-Based Violence

TVEP Thohoyandou Victim Empowerment Programme

UNHCR United Nations High Commission for Refugees

ZTVA Zero Tolerance Village Alliance 


\section{Executive Summary}

The global refugee crisis is one of the most significant challenges of the $21^{\text {st }}$ century. Sexual and genderbased violence (SGBV) exacerbates the already dire situation in refugee settings, and is both a prevalent concern and a complex phenomenon in these contexts. Although SGBV is recognized as a growing problem in emergency settings, and the highest number of forcibly displaced people in recorded history were reported by UNHCR in 2015, evaluations of primary SGBV prevention models in these contexts have remained sparse. This study, therefore, assessed the effectiveness of implementing a community-based SGBV prevention model in emergency settings. Referred to as the 'Zero Tolerance Village Alliance' intervention, the model was implemented in Rwamwanja Refugee Settlement in Kamwenge District, Western Uganda.

The study used a pre- and post-intervention design without a comparison group and was implemented between 2015 and 2016 by the Population Council in collaboration with UNHCR, the Lutheran World Federation, the Thohoyandou Victim Empowerment Programme (the pioneers of the intervention model), the Child Health and Development Centre (Makerere University), and the Refugees Department (Office of the Prime Minister, Uganda).

The study demonstrated that the 'Zero Tolerance Village Alliance' model is an effective means of fostering SGBV prevention in emergency settings. The model proved to be particularly effective in: moderating negative gender attitudes and beliefs related to SGBV; positively changing perceptions of community SGBV norms; reducing the occurrence of physical IPV (for men and women), sexual IPV (for men), non-partner physical violence (for men and women), and non-partner sexual violence (for women); engendering more comprehensive knowledge of rape; and increasing awareness of SGBV interventions. The 'Zero Tolerance Village Alliance' intervention was less effective in changing negative male attitudes toward women's sexual autonomy in intimate partnerships, and in reducing the occurrence of sexual IPV for women. Study findings also suggest that a focus on care-seeking for sexual IPV could be strengthened within the intervention model.

While findings from this evaluation confirmed the overall effectiveness of the 'Zero Tolerance Village Alliance' model in emergency contexts, they also highlighted important issues which have implications for SGBV programming in general in emergency settings in sub-Saharan Africa. These issues are outlined in the remainder of this report for SGBV program consideration, and include: the low literacy levels which characterize some emergency settings; the need to develop targeted approaches for reaching women with SGBV information; the need to address rape-related pregnancy in emergency contexts; the need to stimulate demand for, and increase access to, post-rape care services; and the potential benefit of re-configuring residential arrangements for female-headed households in emergency settings as a preventive measure. 


\section{Background}

The global refugee crisis has been aptly described as "one of the defining challenges of the $21^{\text {st }}$ century." 1 Sexual and gender-based violence (SGBV) exacerbates the already dire situation in refugee settings, and is both a prevalent concern and a complex phenomenon in these contexts. Conflict-related rape, increased intimate partner violence (IPV) during conflict, and IPV which may intensify post-conflict, are just some of the predicaments confronted by refugee populations. ${ }^{2}$ Furthermore, evidence indicates that sexual exploitation by aid workers is a reality in emergency settings. ${ }^{3}$ All facets of women's health (including physical, sexual and reproductive, mental, and behaviorial) are impacted by SGBV-sometimes for the long term and in a chronic manner. ${ }^{4}$ Moreover, polyvictimization (the experience of multiple kinds of violence at the same time) tends to exacerbate health consequences further over time. ${ }^{5}$

SGBV is recognized as a growing problem in emergency contexts, and in 2015, UNHCR reported the highest number of forcibly displaced people in recorded history. ${ }^{6}$ Nonetheless, evaluations of primary SGBV prevention models in emergency settings have remained sparse. ${ }^{7}$ This study, therefore, assessed the effectiveness of implementing a community-based prevention model in emergency settings.

This 'Zero Tolerance Village Alliance' intervention was pioneered by the Thohoyandou Victim Empowerment Programme (TVEP) in rural South Africa. The intervention was introduced and assessed in an emergency context to support the operationalization of the United Nations High Commission for Refugees' (UNHCR) current strategy for Action Against Sexual and Gender-Based Violence. This strategy includes recommended actions in three key areas to strengthen UNHCR's capacity and expertise in addressing SGBV:

1. Data collection and analysis-Improve the quality of programs by adopting and maintaining appropriate SGBV data collection and analysis tools and working with institutions and partners on researching and documenting SGBV;

2. Knowledge management and capacity-building-Strengthen the management of SGBV programs by investing in capacity-building and expertise across the organization; and

3. Partnerships and coordination-Working with UN agencies, governments, non-governmental organizations, and displaced communities, strengthen SGBV prevention, response, and coordination mechanisms for effective service.

\section{Study Aim}

The study aimed to assess the effectiveness of the SGBV prevention model (referred to as the 'Zero Tolerance Village Alliance' model) in emergency contexts.

The study hypothesized that men and women in emergency settings where the 'Zero Tolerance Village Alliance' model is implemented would be:

- Less likely to hold tolerant attitudes towards SGBV than before;

- Less likely to experience SGBV than before; and

- More likely to seek SGBV care than before.

\footnotetext{
Amnesty International. 2015. The global refugee crisis: A conspiracy of neglect. Amnesty International: London, UK., p. 7.

2 Miller L. n.d. The irony of refuge: Gender-Based Violence against Female Refugees in Africa. Human Rights and Human Welfare: www.du.edu/korbel/hrhw/researchdigest/minority/Africa.pdf.

3 UN $57^{\text {th }}$ session Agenda item 122 Report of the Secretary-General on the activities of the Office of Internal Oversight Services Investigation into sexual exploitation of refugees by aid workers in West Africa. Note by Secretary General. 2002. www.un.org/news/dh/infocus/a-57-465.pdf.

4 UNFPA \& WAVE. 2014. Strengthening health system responses to gender-based violence in Eastern Europe and Central Asia: A Resource Package. UNFPA: Istanbul, Turkey.

5 Ibid.

6 Tappis, H., Freeman, J., Glass, N., Doocy, S. 2016. Effectiveness of intervnetions, programs and strategies for GBV prevention in refugee populations: An integrative review. PLOS Currents: Disasters.

7 Ibid.
} 


\section{Study Context 8}

This study took place in Uganda, which has a total refugee population of over 200,000, with a steady influx of refugees over the years from various neighboring countries, fleeing conflict and violence. The Ugandan policy for refugees centers on actual settlement. Consequently, once registered at transit centers, refugees are transferred to settlements (as opposed to 'camp' settings), and provided with land (1.25 acres per household for housing and agriculture) to re-establish their lives. Rwamwanja Settlement in Kamwenge District of Western Uganga served as the study site. Established in 1963-64, this site was selected in consultation with UNHCR and its implementing partners. The setting was selected for its status as a 'long term' emergency context with the stability and structures required to foster SGBV prevention. Refugees residing in this settlement are primarily from the Democratic Republic of Congo (DRC), where violence was noted as a key reason for flight. SGBV was also observed to be a concern within their new settlement home in Rwamwanja.

As the onset of the study in 2015, Rwamwanja was hosting about 40,000 refugees, and continued settlement of new arrivals was expected until a maximum capacity of 55,000 to 60,000 . The settlement is situated on about 108.5 square kilometers comprising 15 zones and 45 villages. Persistent conflict in North Kivu province of DRC is responsible for the movement of many Congolese across the Ugandan border. During a period when refugees repatriated, leaving the land vacant, Rwamwanja was occupied illegally by nationals. The arrival of the first convoy of Congolese refugees to Rwamwanja in April 2012 caused tension between the nationals and refugees, leading to spates of violence and enhanced security subsequently.

Within Rwamwanja Settlement, Kyempango 'A' zone was selected as the study site by UNHCR in collaboration with its implementing partners and the Office of the Prime Minister, based on high reported rates of rape and defilement in this particular zone. Villages 1 and 3 of Kyempango ' $A$ ' zone served as the specific intervention and research locales. The total population of Kyempango 'A' zone as at July 2016 (4 months after the study ended) is provided below, along with the population breakdown by sex, age, number of households, and number of male-headed and female-headed. It is important to note, however, that there are population shifts in Kyempango 'A,' as well as in the overall Settlement, as some new entrants are incorporated into the villages, and old residents move from one village to another, or return from sojourns outside of Rwamwanja.

\begin{tabular}{|c|c|c|c|c|c|c|c|c|c|}
\hline \multirow[t]{2}{*}{$\begin{array}{c}\text { Kyempango } \\
\text { A Village }\end{array}$} & \multirow[t]{2}{*}{$\begin{array}{c}\text { Total } \\
\text { Population }\end{array}$} & \multirow[t]{2}{*}{ Males } & \multirow[t]{2}{*}{ Females } & \multicolumn{3}{|c|}{ Age range } & \multirow{2}{*}{$\begin{array}{c}\begin{array}{c}\text { Total \# } \\
\text { of } \\
\text { Households }\end{array}\end{array}$} & \multirow{2}{*}{$\begin{array}{c}\text { \# Male- } \\
\text { Headed } \\
\text { Households }\end{array}$} & \multirow{2}{*}{$\begin{array}{c}\text { \# Female- } \\
\text { Headed } \\
\text { Households }\end{array}$} \\
\hline & & & & $0-17$ & $18-45$ & $45+$ & & & \\
\hline Village A1 & 1,044 & 523 & 521 & 629 & 350 & 65 & 238 & 173 & 65 \\
\hline Village A2 & 1,046 & 492 & 554 & 640 & 339 & 67 & 223 & 149 & 74 \\
\hline Village A3 & 1,539 & 784 & 755 & 996 & 483 & 60 & 351 & 228 & 123 \\
\hline Village A4 & 1,338 & 665 & 673 & 869 & 398 & 73 & 253 & 149 & 74 \\
\hline Village A5 & 1,358 & 652 & 706 & 835 & 463 & 60 & 281 & 198 & 83 \\
\hline
\end{tabular}

\section{Study Design}

The study used a pre- and post-intervention design without a comparison group. The overall study was implemented from May 2015 to March 2016 by the Population Council in collaboration with the Lutheran World Federation (LWF), TVEP, the Child Health and Development Centre (Makerere University), the Refugees Department (Office of the Prime Minister, Uganda), and UNHCR.

\footnotetext{
8 Information for this section is derived primarily from consultations with the UNHCR Regional Services Centre, UNHCR Kampala, and a 2012 LWF publication available here: www.actalliance.org/resources/appeals/UGA121_CongRef.pdf.
} 


\section{Intervention Description}

This intervention occurred over six months (September 2015 to February 2016). TVEP, the pioneer of the 'Zero Tolerance Village Alliance' (ZTVA) model, trained LWF in the ZTVA methodology over eight days, and supported the intervention implementation process via two technical assistance visits to Rwamwanja Settlement. The components of the ZTVA methodology applied in Kyempango 'A' zone were as follows:

Community Mapping and Dialogues: A community mapping exercise helped to identify all structures and agencies that could be targeted for involvement in the intervention. The mapping exercise also helped to identify other organizations providing SGBV services in the sites in order to avoid the duplication of effort. Dialogues were then held with community members in the intervention site to provide information about the intervention and promote community ownership.

Establishment of a Stakeholder Forum: A Stakeholder Forum, representative of structures and agencies in Kyempango ' $A$ ' zone (i.e., community leadership, churches, education, and business) was appointed. All stakeholders were community residents with proven track records demonstrating commitment to gender equality, gender justice, and leadership. Stakeholder Forum members held meetings every month to evaluate the intervention implementation carried out by LWF, and to ensure community members attended training workshops under the intervention. Furthermore, Stakeholder Forum members were charged with attending all training workshops on SGBV developed specifically for them.

Signing a Memorandum of Agreement (MoA): Stakeholder Forum members signed a MoA to help formalize and guide the partnership between the Forum and LWF. The MoA outlined the intervention's expectations of Forum members (including having a functional Forum, with representation from specific sectors; having conducted community mapping, followed by training of key stakeholders identified through the process; having a safe house for survivors; ensuring that health facilities provided male and female condoms, etc.). In turn, the support that the Forum could expect from LWF was delineated, and included technical assistance in implementing aspects of the intervention. The MoA also emphasized that any unresolvable breach of contract would result in the termination of the agreement.

Training: LWF trained various key groups by sensitizing them on SGBV-related issues, including domestic violence, sexual abuse, child abuse, family planning, and HIV. The following groups received training on these issues: Stakeholder Forum members $(n=90)$, community peer educators $(n=17)$, and male and female community members $(n=960)$. Leaflets to summarize training lessons were distributed and reviewed during the training sessions. Each trainee was encouraged to independently train two other community members after receiving their own individual training (an approach referred to by LWF as 'Each One, Teach Two').

Pledge-Taking Ceremony: Once the expectations outlined in the MoA were achieved by the participating intervention sites, LWF sponsored a joint public ceremony for them. At the ceremony, the men of the intervention communities were invited to take a public pledge to proactively address the eradication of SGBV in their villages. They were led in this pledge/oath by the Magistrate (Grade 1) of Kamwenge District. All men taking the pledge were asked to sign a 'Roll of Honor,' which was later stored in a secure location available to the public in the village. Such men were also given an LWF 'Badge of Honor' to identify them as pledgetakers. Female and male community members who had 'broken the silence' by taking some form of action against SGBV during the intervention implementation period were also recognized at the ceremony, and awarded 'Badges of Courage.' The ceremony was used as a platform to publicly announce that men who subsequently breached the pledge would have their names removed from the 'Roll of Honor' by the Stakeholder Forum.

Alliance Identification: At the pledge-taking ceremony, the participating villages were given a large billboard, indicating the village names and declaring their 'zero-tolerance' status and induction into an 'Alliance' of zero-tolerance villages. A small allowance was also made available for the villages to use in building a sense of community after the ceremony. The villages concerned chose to purchase crockery (large cooking pots and spoons, plates, cutlery) to facilitate large functions in the community, such as funerals and celebrations. 


\section{Theoretical Underpinnings}

The ZTVA intervention is undergirded by two theories, namely, achievement motivation theory and labeling theory. Achievement motivation theory contends that three dominant needs underpin human motivation: the need for achievement, the need for power, and the need for affiliation - and the relative importance of each is thought to vary among individuals and cultures. The need for achievement is particularly relevant to the ZTVA approach, as it involves 'be[ing] successful in terms of competition with some standard of excellence. The individual may fail to achieve this goal, but the concern over competition with a standard of excellence still enables one to identify the goal sought as an achievement goal.' 9 Direct competition seems to motivate individuals to compete with a standard of excellence, although such competition is not mandatory for motivation. ${ }^{10}$

Labeling theory centers on how individuals' self-identity and behavior may be influenced by the terms used to describe or classify them. Labeling occurs when an identity is imposed on an individual - usually by a more powerful person. ${ }^{11}$ Individuals can internalize the labels given to them, imposing them on themselves. ${ }^{12}$

The ZTVA model harnesses the need for achievement in communities, and provides a 'standard of excellence,' represented by criteria communities must meet before induction into an alliance of like-minded 'Zero Tolerance' villages or communities. The competition with other villages or communities inherent in the ZTVA approach is meant to further motivate communities to acquire and maintain 'Zero Tolerance' status. Moreover, being labeled as a 'Zero Tolerance' zone against SGBV is presumed to have the effects of a selffulfilling prophecy. These theoretical models are activated to result in reorientation and behavior change. Ultimately, positive changes in SGBV are expected to be observed in communities over time, and have been noted in parts of rural South Africa where the ZTVA model has been implemented and tested. ${ }^{13}$

\section{Data Collection}

Data collection among household heads occurred before and after the intervention, and the process involved the administration of structured questionnaires to respondents by trained research assistants. Baseline and endline data collection occurred in May and June 2015, and February and March 2016, respectively.

The study tools for men and women were similar, with the exception of a few domains that were irrelevant to men (e.g. questions on experience of pregnancy). A considerable proportion of the study tool items were adapted from the GEM (Gender Equitable Men) Scale ${ }^{14}$-an instrument measuring views of gender norms, and which has been applied or referenced over 150 times in sub-Saharan Africa, Asia, and Latin America since its development. Studies on the GEM scale suggest it is a sensitive and cross-culturally relevant tool, with good predictive validity. ${ }^{15}$ The GEM Scale has been used effectively with both men/boys and women/girls, and its adaptations in various contexts have been successful. ${ }^{16}$

Only household heads were eligible for participation in the interviews - a deliberate decision due to ethical concerns related to the sensitivity of SGBV and its high prevalence in Kyempango, in order to help ensure female interviewees' protection in particular. As female household heads are likely have more autonomy

\footnotetext{
9 McClelland DC, JW Atkinson, RA Clark, EL Lowell. 1958. A scoring manual for the achievement motive. In J.W Atkinson (Ed), Motives in fantasy, action, and society (179-204). Princeton: D. Van Nostrand Co. Cited in Moore LL, GK Grabsch, C Rotter. 2010. Using achievement theory to explain student participation in a residential leadership learning community. J of Leadership Ed 9(2).

10 Ibid.

11 O’Byrne D. 2013. Introducing sociological theory. Routledge: New York.

12 Ibid.

13 Nicholson F, C Carty. 2015. The 'Zero Tolerance Village Alliance': A promising intervention for addressing sexual and gender-based violence in rural communities. BMC Proceedings 9(Suppl 4): A4.

14 Pulerwitz J, G Barker. 2008. Measuring attitudes toward gender norms among young men in Brazil: Development and psychometric evaluation of the GEM Scale. Men and Masculinities 10: 322-338.

15 Pulerwitz, J. 2016. Gender transformational programming and measurement for HIV and IPV reduction. Presentation at Johns Hopkins Bloomberg School Seminar Series. March 2016. www.jhsph.edu/departments/population-family-and-reproductivehealth/news-and-events/wednesday-seminars/2015-2016-presentations/03-23\%20Pulerwitz.pdf

16 Ibid.
} 
over their own decisions (e.g. to participate in an interview), and are presumably less likely to suffer SGBV as a result of study participation, household heads were selected as sole study participants.

Information was collected on basic socio-demographic characteristics (e.g. age, sex, education), attitudes toward SGBV, experiences of SGBV, and exposure to the intervention. The survey tools for men and women were translated into Kiswahili (commonly spoken by the primarily Congolese study population) and pretested. Four experienced research assistants (2 male, 2 female) were trained on SGBV, the project goals, tools contents, community entry, quantitative data collection, and ethics, for five days. The research assistants were Kiswahili speakers, and respondents were interviewed by interviewers of the same sex.

The study received ethical and research clearance from the National HIV/AIDS Research Committee and the Uganda National Council for Science and Technology in Uganda. In addition, ethical approval was obtained from the Institutional Review Board of the Population Council. Individual, written informed consent was obtained from all participants before conducting the interviews.

All households in each of the selected villages were visited, and every household head available was invited to participate in an interview. Those that satisfied the following criteria were eligible for individual interviews:

- Female household head aged 12 and older

- Male household head aged 12 and older

\section{Data Analysis}

The data were collected using tablets, downloaded into ACCESS database, and subsequently analyzed using STATA. The effect of the intervention is assessed by comparing the indicators for the two study sites combined at baseline and at endline, and testing for any significant differences between these two time periods. The intervention was considered to have had an effect if significant differences were found between baseline and endline.

The results are presented as frequencies and percentages. Chi-square tests and significance tests of proportions are also conducted to determine if the observed differences between the two time periods are statistically significant.

\section{Key Findings}

\section{Characteristics of Household Heads}

Table 1 presents the socio-demographic characteristics of the respondents interviewed at baseline and endline. Although efforts were made to include equal numbers of men and women, the proportion of male respondents was higher than that of female respondents. This was expected given that household headship has conventionally been a male preserve.

Almost all respondents (99\%) originated from the Democratic Republic of Congo (DRC) (not shown). Most respondents had lived in Kyempango ' $A$ ' zone for more than two years (Table 1). 
Table 1: Percent distribution of study participants by background characteristics

\begin{tabular}{|c|c|c|c|c|}
\hline & \multicolumn{2}{|c|}{ Men } & \multicolumn{2}{|c|}{ Women } \\
\hline & $\begin{array}{c}\text { Baseline } \\
n=340\end{array}$ & $\begin{array}{c}\text { Endline } \\
n=336\end{array}$ & $\begin{array}{c}\text { Baseline } \\
n=261\end{array}$ & $\begin{array}{c}\text { Endline } \\
n=299\end{array}$ \\
\hline & $\%$ & $\%$ & $\%$ & $\%$ \\
\hline \multicolumn{5}{|l|}{ Age at last birthday } \\
\hline 10-14 years & 0.0 & 0.0 & 0.8 & 0.0 \\
\hline $15-19$ years & 2.6 & 1.8 & 7.7 & 4.3 \\
\hline $20-24$ years & 14.1 & 13.4 & 21.1 & 16.1 \\
\hline 25-29 years & 20.0 & 20.5 & 21.8 & 23.1 \\
\hline $30-34$ years & 16.5 & 15.5 & 16.5 & 18.4 \\
\hline $35-39$ years & 14.7 & 15.2 & 8.0 & 11.0 \\
\hline 40-44 years & 11.2 & 9.8 & 12.6 & 8.7 \\
\hline 45 years and above & 20.6 & 23.8 & 11.5 & 18.4 \\
\hline Don't know & 0.3 & 0.0 & 0.0 & 0.0 \\
\hline \multicolumn{5}{|c|}{ Duration of stay in Kyempango A settlement } \\
\hline Less than 1 Year & 1.8 & 6.0 & 3.8 & 9.7 \\
\hline 1-2 Years & 28.5 & 7.7 & 31.4 & 5.4 \\
\hline More than 2 Years & 69.7 & 86.3 & 64.8 & 84.9 \\
\hline \multicolumn{5}{|c|}{ What do you do for a living here in Kyempango $A$ ? } \\
\hline Nothing (not a student, either) & 4.4 & 3.9 & 5.4 & 5.7 \\
\hline Student & 0.3 & 0.0 & 0.0 & 0.0 \\
\hline Farmer & 80.9 & 84.5 & 91.2 & 89.3 \\
\hline Trader & 2.4 & 3.6 & 1.5 & 2.7 \\
\hline Tailor & 0.9 & 0.9 & 1.1 & 0.0 \\
\hline Other [specify] & 11.2 & 7.1 & 0.8 & 2.3 \\
\hline \multicolumn{5}{|c|}{ What is the highest level of school you have attended? } \\
\hline No schooling & 33.8 & 36.0 & 68.6 & 73.2 \\
\hline Primary incomplete & 41.2 & 41.1 & 25.7 & 22.7 \\
\hline Primary complete & 5.9 & 3.0 & 0.8 & 0.3 \\
\hline Secondary incomplete & 12.9 & 13.7 & 3.5 & 2.7 \\
\hline Secondary complete & 2.7 & 3.6 & 1.2 & 0.3 \\
\hline College/Tertiary incomplete & 1.2 & 0.3 & 0.0 & 0.3 \\
\hline College/Tertiary complete & 2.4 & 2.4 & 0.4 & 0.3 \\
\hline Other [specify] & 0.0 & 0.0 & 0.0 & 0.0 \\
\hline
\end{tabular}

The level of education among respondents was generally low (Table 1). Approximately half of the respondents had no formal education. The proportion of women with no formal education was at least twice that of men.

The majority of respondents (85\% at baseline, $87 \%$ at endline) practiced farming as their occupation (not shown), reflecting the utility of the Ugandan policy of actual settlement for refugees, who are provided with land for housing and agriculture upon arrival.

\section{Attitudes and Beliefs}

\section{Physical intimate partner violence}

Indicators of attitudes towards physical intimate partner violence were captured through a series of statements focusing on gender norms in intimate partnerships, or differing social expectations for men and women. Household heads were asked to indicate whether they agreed, disagreed, or were not sure about the justifiability of men's physical violence toward their partners if it resulted from their being angry - or from their being denied sex, food, or money. At endline, the proportion of respondents that disagreed with these statements was significantly higher for both male and female household heads (Table 2). 
Table 2: Percent distribution of respondents disagreeing with justification for physical IPV

\begin{tabular}{|c|c|c|c|c|}
\hline \multirow[b]{2}{*}{ Indicators of attitudes and beliefs } & \multicolumn{2}{|c|}{ Men } & \multicolumn{2}{|c|}{ Women } \\
\hline & $\begin{array}{c}\text { Baseline } \\
n=340\end{array}$ & $\begin{array}{l}\text { Endline } \\
\mathrm{n}=336\end{array}$ & $\begin{array}{c}\text { Baseline } \\
n=261\end{array}$ & $\begin{array}{l}\text { Endline } \\
n=299\end{array}$ \\
\hline $\begin{array}{l}\text { Men are justified in hitting or beating their } \\
\text { wives/partners/girlfriends when they are... }\end{array}$ & (\%) & (\%) & (\%) & (\%) \\
\hline ... angry & 82.9 & $95.2 * * *$ & 52.1 & $96.7 * * *$ \\
\hline ... denied sex & 93.8 & $98.8 * * *$ & 46.4 & $94.0 * * *$ \\
\hline ... denied food & 93.8 & $98.8 * * *$ & 54.0 & $91.0 * * *$ \\
\hline ... denied money & 91.8 & $97.6 * * *$ & 60.5 & $94.0 * * *$ \\
\hline
\end{tabular}

Attitudes and beliefs about male sexual self-control and women's sexual autonomy were measured via two separate statements about which household heads were asked to indicate agreement, disagreement, or uncertainty. The first statement indicated that men and boys were created with the inability to exercise sexual self-control, and the second proffered that women and girls had the right to decline sex with intimate partners if they were unwilling. The proportions of men and women reporting that they disagreed that men and boys were naturally unable to exercise sexual self-control increased significantly at endline (Table 3 ).

Among women, the proportion of those who agreed that women have the right to say no to sex with their partners was significantly higher at endline than at baseline (Table 3). Among male respondents, there was no significant difference in the proportions that agreed with this statement between the two surveys (Table 3).

Table 3: Percent distribution of respondents agreeing with statements on male sexual self-control and women's sexual autonomy

\begin{tabular}{|c|c|c|c|c|}
\hline & & & Wor & ien \\
\hline & $\begin{array}{c}\text { Baseline } \\
\mathrm{n}=340\end{array}$ & $\begin{array}{l}\text { Endline } \\
\mathrm{n}=336\end{array}$ & $\begin{array}{c}\text { Baseline } \\
n=261\end{array}$ & $\begin{array}{l}\text { Endline } \\
\mathrm{n}=299\end{array}$ \\
\hline & (\% Agree) & (\% Agree) & (\% Agree) & (\% Agree) \\
\hline $\begin{array}{l}\text { 'It is not possible for men/boys to control sexual } \\
\text { urges-that is just how they were created.' }\end{array}$ & 41.8 & $16.4 * * *$ & 83.1 & $35.1 * * *$ \\
\hline $\begin{array}{l}\text { 'A woman/girl has the right to refuse sex with her } \\
\text { man if she does not want to have sex at that time.' }\end{array}$ & 77.1 & 83.0 & 53.6 & $73.2 * * *$ \\
\hline
\end{tabular}

\section{Knowledge of rape}

The comprehensiveness of participants' knowledge of rape was also examined. Respondents were presented with a series of rape definitions, including female sexual coercion by a stranger, partner, or relative. Respondents were then asked to indicate whether they agreed or disagreed with these statements. No significant differences were observed in the proportion of men who agreed with these statements by endline. However, it is important to note that very high proportions of men agreed with the statements at both time periods. Among women, the proportion that agreed with the definition of rape as being female sexual coercion by a partner or by a relative was significantly higher at endline than at baseline (Table 4).

Table 4: Percent distribution of respondents agreeing rape definitions

\begin{tabular}{|l|c|c|c|c|}
\hline & \multicolumn{2}{|c|}{ Men } & \multicolumn{2}{c|}{ Women } \\
\hline & $\begin{array}{c}\text { Baseline } \\
\mathrm{n}=340\end{array}$ & $\begin{array}{c}\text { Endline } \\
\mathrm{n}=336\end{array}$ & $\begin{array}{c}\text { Baseline } \\
\mathrm{n}=\mathbf{2 6 1}\end{array}$ & $\begin{array}{c}\text { Endline } \\
\mathrm{n}=299\end{array}$ \\
\hline $\begin{array}{l}\text { Rape is when a woman/girl is forced to } \\
\text { have sex against her will by... }\end{array}$ & (\% Agree) & (\% Agree) & (\% Agree) & $(\%$ Agree) \\
\hline$\ldots$ a stranger & 99.1 & 100.0 & 95.4 & 99.3 \\
\hline$\ldots$ a relative & 98.5 & 99.7 & 87.0 & $100.0 * \star \star$ \\
\hline$\ldots$ her man & 87.4 & 86.9 & 64.0 & $96.0 * \star \star$ \\
\hline$\star * \star p<0.001$ & \multicolumn{3}{|l}{} \\
\hline
\end{tabular}




\section{Perceptions of community SGBV norms}

A series of statements was presented to participants, centering on community norms in regard to SGBV. The statements examined perceptions of the normalcy of physical and sexual violence toward men and women in the study sites. At endline, the proportion of men and women alike who agreed that it was normal for females and males in their community to be forced to have sex, and for females to get beaten up in their community, decreased significantly (Table 5). The proportion of men who agreed it was normal for males to get beaten up decreased significantly between baseline and endline surveys. However, there was no significant difference in the proportion of women that agreed with this particular statement between surveys (Table 5).

Table 5: Percent distribution of respondents agreeing with SGBV norm statements

\begin{tabular}{|c|c|c|c|c|}
\hline & \multicolumn{2}{|c|}{ Men } & \multicolumn{2}{|c|}{ Women } \\
\hline & $\begin{array}{c}\text { Baseline } \\
n=340\end{array}$ & $\begin{array}{c}\text { Endline } \\
n=336\end{array}$ & $\begin{array}{c}\text { Baseline } \\
n=261\end{array}$ & $\begin{array}{l}\text { Endline } \\
\mathrm{n}=299\end{array}$ \\
\hline In Kyempango A zone, it is normal for ... & (\% Agree) & (\% Agree) & (\% Agree) & (\% Agree) \\
\hline ...women and/or girls to be forced to have sex & 47.1 & $4.2 * * *$ & 80.1 & $10.7 * \star *$ \\
\hline ... women and/or girls to get beaten up & 58.8 & $8.6 * * *$ & 76.6 & $15.7 * * *$ \\
\hline ... men and/or boys to be forced to have sex & 14.7 & $2.3 * * *$ & 13.0 & $2.3 * * *$ \\
\hline ... men and/or boys to get beaten up & 51.8 & $7.4 * * \star$ & 7.3 & 7.4 \\
\hline
\end{tabular}

\section{Experience of, and care-seeking for, SGBV}

\section{Experience of intimate partner violence}

Experience of physical and sexual IPV was measured by questions on whether respondents currently in intimate partnerships had ever been harmed physically or forced to have sex by their current partner. There were significant decreases among male and female respondents in the proportions reporting any physical IPV by their current partner (Table 6). The proportion of male participants reporting ever experiencing sexual IPV by current partner decreased significantly between baseline and endline. There were no significant differences, however, in the proportion of women reporting the same between surveys (Table 6).

Table 6: Percent distribution of respondents who experienced sexual IPV

\begin{tabular}{|l|c|c|c|c|}
\hline & \multicolumn{2}{|c|}{ Men } & \multicolumn{2}{c|}{ Women } \\
\cline { 2 - 5 } & $\begin{array}{c}\text { Baseline } \\
\mathrm{n}=247\end{array}$ & $\begin{array}{c}\text { Endline } \\
\mathrm{n}=262\end{array}$ & $\begin{array}{c}\text { Baseline } \\
\mathrm{n}=35\end{array}$ & $\begin{array}{c}\text { Endline } \\
\mathrm{n}=29\end{array}$ \\
\hline & $(\%)$ & $(\%)$ & $(\%)$ & $(\%)$ \\
\hline $\begin{array}{l}\text { Does your man/woman ever hurt you } \\
\text { physically in any way (e.g. beat you, slap/ } \\
\text { punch/kick/push/drag you)? }\end{array}$ & 5.7 & $1.9 *$ & 68.6 & $37.9 *$ \\
\hline $\begin{array}{l}\text { Does your man/woman ever force you to have } \\
\text { sex with him even when you do not want to? }\end{array}$ & 4.1 & $0.0 * * *$ & 62.9 & 41.4 \\
\hline$* * * p<0.001, \star p<0.05$ & \multicolumn{3}{|l}{} \\
\hline
\end{tabular}

\section{Experience of non-partner violence}

Respondents were asked whether they had ever experienced non-partner physical violence since they started residing in Rwamwanja Settlement-and if so, whether this had occurred in the month preceding the survey. They were also asked if they had ever experienced non-partner sexual violence since they became Kyempango ' $A$ ' residents, and whether this had happened in last month, if so.

At endline, the proportions of men and women reporting ever experiencing non-partner physical violence since residing in Rwamwanja Settlement were not significantly different from those at baseline. A significant decrease was observed, however, in the proportions of men and women reporting experiences of non-partner physical violence in the month preceding the endline survey (Table 6). Similarly, between baseline and endline, there were no differences in the proportions of men and women indicating non-partner sexual 
violence since living in Kyempango 'A.' The proportion of women indicating experience of this form of violence in the last month had decreased significantly, however, by endline. Only a small number of men reported non-partner sexual violence during the study period. Nonetheless, none of the men reported experiencing this form of violence in the last one month at endline compared to seven out of 13 at baseline (Table 7).

Table 7: Respondents' experience of non-partner physical and sexual violence

\begin{tabular}{|l|c|c|c|c|}
\hline \multirow{2}{*}{} & \multicolumn{2}{|c|}{ Men } & \multicolumn{2}{c|}{ Women } \\
\cline { 2 - 5 } & $\begin{array}{c}\text { Baseline } \\
\mathrm{n}=340\end{array}$ & $\begin{array}{c}\text { Endline } \\
\mathrm{n}=336\end{array}$ & $\begin{array}{c}\text { Baseline } \\
\mathrm{n}=261\end{array}$ & $\begin{array}{c}\text { Endline } \\
\mathrm{n}=299\end{array}$ \\
\cline { 2 - 5 }$(\%)$ & $(\%)$ & $(\%)$ & $(\%)$ \\
\hline $\begin{array}{l}\text { Since you started living in Rwamwanja, has } \\
\text { anyone [other than your man/woman] ever hurt } \\
\text { you physically in any way (e.g. beat you, slapped/ } \\
\text { punched/kicked/pushed/dragged you)? }\end{array}$ & 27.4 & 28.9 & 46.7 & 40.1 \\
\hline $\begin{array}{l}\text { Since you started living in Kyempango A, has } \\
\text { anyone [other than your man/woman] ever forced } \\
\text { you to have sex against your will? }\end{array}$ & 3.8 & 1.8 & 46.0 & 44.8 \\
\hline & $\mathrm{n}=93$ & $\mathrm{n}=97$ & $\mathrm{n}=122$ & $\mathrm{n}=120$ \\
\hline $\begin{array}{l}\text { In the last one month, has anyone [other than your } \\
\text { man/woman] ever hurt you physically in any way } \\
\text { (e.g. beat you, slapped/punched/kicked/pushed/ } \\
\text { dragged you)? }\end{array}$ & 34.4 & $6.2 * * *$ & 11.5 & $4.2 *$ \\
\hline & $\mathrm{n}=13$ & $\mathrm{n}=6$ & $\mathrm{n}=121$ & $\mathrm{n}=134$ \\
\hline $\begin{array}{l}\text { In the last one month, has anyone [other than your } \\
\text { man/woman] ever forced you to have sex against } \\
\text { your will? }\end{array}$ & 54.0 & 0.0 & 12.5 & $5.2 *$ \\
\hline$* * * p<0.001, * p<0.05$ & & & & \\
\hline
\end{tabular}

For the small number of cases that reported experiencing non-partner sexual violence in the month preceding the baseline and endline surveys, this form of violence was more likely to be experienced by women at home, and by men outside the home (not shown). Non-partner sexual violence was reported to have occurred at home for 11 out of 15 women reporting this form of violence in the last one month at baseline, and for five out of seven women reporting the same in the last one month at endline. In contrast, all men who reported experiencing non-partner sexual violence in the last one month at baseline $(n=7)$, had this experience outside the home.

\section{Care-seeking for SGBV}

A series of statements presented to participants assessed their perceptions of the importance and value of care-seeking at health facilities and police stations for SGBV in general (i.e. including non-partner violence, and not limited to IPV). Between baseline and endline interviews, the proportion of respondents that agreed with the following statements was significantly higher at endline than baseline: that immediate reporting to the police by the victim is important when coerced sex occurs (men and women); that immediate reporting to the police by the victim is worth it when coerced sex occurs (women); and that reporting to a health center or to police within 72 hours of the incident is important when coerced sex occurs (men and women) (Table 8). 
Table 8: Percent distribution of respondents by perception of value of care-seeking from health facilities and police after rape

\begin{tabular}{|c|c|c|c|c|}
\hline & \multicolumn{2}{|c|}{ Men } & \multicolumn{2}{|c|}{ Women } \\
\hline & $\begin{array}{c}\text { Baseline } \\
n=340\end{array}$ & $\begin{array}{l}\text { Endline } \\
n=336\end{array}$ & $\begin{array}{c}\text { Baseline } \\
\mathrm{n}=\mathbf{2 6 1}\end{array}$ & $\begin{array}{l}\text { Endline } \\
\mathrm{n}=299\end{array}$ \\
\hline & $(\%)$ & $(\%)$ & $(\%)$ & $(\%)$ \\
\hline When one has been forced to have sex against their will... & & & & \\
\hline $\begin{array}{l}\text {... it is important to report this to the health center } \\
\text { immediately. }\end{array}$ & 94.1 & 95.5 & 92.7 & 95.0 \\
\hline $\begin{array}{l}\ldots \text { it is worth it to report this to the health center } \\
\text { immediately. }\end{array}$ & 94.4 & 95.8 & 85.8 & 94.0 \\
\hline ... it is important to report this to the police immediately. & 77.4 & $92.9 * * *$ & 49.8 & $59.9 *$ \\
\hline ... it is worth it to report this to the police immediately. & 90.9 & 93.2 & 62.8 & $80.3 * * *$ \\
\hline $\begin{array}{l}\ldots \text { it is important to report this to the health center } \\
\text { and/or police within } 72 \text { hours of the incident. }\end{array}$ & 72.9 & $96.7 * * *$ & 76.2 & 83.3* \\
\hline
\end{tabular}

Nonetheless, those that reported actually experiencing sexual IPV also demonstrated poor care-seeking behavior for this condition. Although the total number of cases reporting sexual IPV was small $(n=32$ at baseline; $n=12$ at endline), few victims of sexual IPV reported seeking health services for such incidents. At baseline, five out of 32 victims sought care at Rwamwanja Health Centre, while at endline, none of the 12 respondents reporting having experienced sexual IPV, sought care for it at Rwamwanja Health Centre. The main reasons for their not seeking health care at baseline included 'did not think it was important,' 'was ashamed,' and 'injuries were not serious.' At endline, the main reasons for not seeking health care included 'was ashamed' and 'did not think it was important.' Respondents' reasons for not seeking health care for non-partner sexual violence were similar to the aforementioned reasons.

\section{Experience of rape-related pregnancy}

To measure rape-related pregnancy, female respondents were asked if they had ever gotten pregnant as a result of sexual IPV. At baseline, 15 out of 22 women who answered this question reported a pregnancy as a result of this form of violence. At endline, nine out of 12 women who responded reported pregnancy due to sexual IPV (not shown). Women who reported ever experiencing non-partner sexual violence in the study site at baseline $(n=121)$ were asked if they had ever gotten pregnant as a result of coercive sex by a nonpartner. Over half of these women (56\%) at baseline had experienced rape-related pregnancy, and at endline nearly half (46\%) had experienced rape-related pregnancy (Table 9).

Table 9: Proportion of female household heads who experienced rape-related pregnancy

\begin{tabular}{|l|c|c|}
\hline $\begin{array}{l}\text { Have you ever gotten pregnant from being forced to have sex } \\
\text { against your will [by someone other than your man/boyfriend]? }\end{array}$ & $\begin{array}{c}\text { Baseline } \\
(\mathrm{n}=120)\end{array}$ & $\begin{array}{c}\text { Endline } \\
(\mathrm{n}=134)\end{array}$ \\
\hline Yes & $\%$ & $\%$ \\
\hline No & 56.7 & 45.5 \\
\hline$* * p<0.01$ & 36.7 & $53.7^{* *}$ \\
\hline No response & 6.7 & 0.8 \\
\hline
\end{tabular}

\section{Awareness of SGBV Interventions}

There was a significant difference in the proportions of men and women indicating awareness of any information campaign in their community about ending violence against men and women, as well as 
awareness of the 'Zero Tolerance Village Alliance' campaign in particular (Table 10). Nonetheless, men were much more likely than women to be aware of SGBV campaigns in general (Table 10).

Table 10: Percent distribution of respondents by awareness of SGBV campaigns

\begin{tabular}{|c|c|c|c|c|}
\hline & \multicolumn{2}{|c|}{ Men (\%) } & \multicolumn{2}{|c|}{ Women (\%) } \\
\hline & $\begin{array}{c}\text { Baseline } \\
\mathrm{n}=340\end{array}$ & $\begin{array}{c}\text { Endline } \\
\mathrm{n}=336\end{array}$ & $\begin{array}{c}\text { Baseline } \\
\mathrm{n}=\mathbf{2 6 1}\end{array}$ & $\begin{array}{l}\text { Endline } \\
\mathrm{n}=\mathbf{2 9 9}\end{array}$ \\
\hline \multicolumn{5}{|c|}{ Are you aware of any information campaign in Kyempango $A$ on stopping violence against women and men? } \\
\hline Yes & 73.8 & $92.0 * * *$ & 29.1 & $73.6 * * *$ \\
\hline No & 25.9 & $8.0 * * *$ & 70.1 & $26.4 * * *$ \\
\hline Missing & 0.3 & 0.0 & 0.8 & 0.0 \\
\hline \multicolumn{5}{|c|}{ Are you aware of an information campaign in Kyempango A called the 'Zero Tolerance Village Alliance'? } \\
\hline Yes & 0.0 & $92.0 * * *$ & 0.4 & $69.6 * * *$ \\
\hline No & 98.8 & $8.0 * \star *$ & 98.8 & $18.4 * * *$ \\
\hline Missing & 1.2 & 0.0 & 0.8 & 12.0 \\
\hline
\end{tabular}

Despite the generally improved awareness of SGBV interventions in the community among the study population, men and women were not at par in their agreement with statements indicating that rape, wifebeating, and physical violence towards others in general were not tolerated in their community. Among men, there were significant increases in the proportion who agreed that these three forms of violence were not tolerated in the community. Among their female peers, there were no significant differences in the proportions who agreed with these same statements (Table 11).

Table 11: Percent distribution of respondents-by agreement

\begin{tabular}{|c|c|c|c|c|}
\hline & \multicolumn{2}{|c|}{ Men } & \multicolumn{2}{|c|}{ Women } \\
\hline & $\begin{array}{c}\text { Baseline } \\
n=340\end{array}$ & $\begin{array}{c}\text { Endline } \\
n=336\end{array}$ & $\begin{array}{c}\text { Baseline } \\
n=261\end{array}$ & $\begin{array}{l}\text { Endline } \\
n=299\end{array}$ \\
\hline The Kyempango A community does not tolerate.... & (\%) Agree & (\%) Agree & (\%) Agree & (\%) Agree \\
\hline ... rape & 87.1 & $94.0 * *$ & 88.5 & 86.6 \\
\hline ... wife-beating & 82.9 & $93.8 * \star *$ & 87.7 & 84.3 \\
\hline$\ldots$ the beating up of others & 81.8 & $92.6 * \star *$ & 83.5 & 84.6 \\
\hline
\end{tabular}

\section{Conclusion}

The study hypothesized that men and women in emergency settings where the 'Zero Tolerance Village Alliance' model is adapted and implemented would be:

- Less likely to hold tolerant attitudes towards SGBV than before;

- Less likely to experience SGBV than before; and

- More likely to seek SGBV care than before.

Related to the hypothesis, the model proved particularly effective in: moderating negative gender attitudes and beliefs related to SGBV; positively changing perceptions of community SGBV norms; reducing the occurrence of physical IPV (for men and women), sexual IPV (for men), non-partner physical violence (for men and women), and non-partner sexual violence (for women); engendering more comprehensive knowledge of rape; and increasing awareness of SGBV interventions. The Zero Tolerance Village Alliance intervention was less effective in changing negative male attitudes toward women's sexual autonomy in intimate partnerships, and in reducing the occurrence of sexual IPV for women. Study findings also suggest that a focus on careseeking for sexual IPV could be strengthened within the intervention model. 
Overall, however, the study demonstrates that the Zero Tolerance Village Alliance model is an effective means of fostering SGBV prevention in emergency settings.

\section{Recommendations for Programming}

While findings from this evaluation confirm the effectiveness of the Zero Tolerance Village Alliance model in emergency contexts, they also highlight important issues which have implications for SGBV programming in general in emergency settings in sub-Saharan Africa. These issues are outlined here for SGBV program consideration, along with recommendations for addressing them.

1. Levels of formal education were found to be low in this emergency context - particularly among women, who were at least twice as likely as their male counterparts to have never been to school. This implies low literacy levels among overall population. Yet, many SGBV responses in these settings tend to be literacy-based, involving the use of bill boards, posters, leaflets, etc.

Recommendation: Ensure that SGBV interventions in emergency settings include a balance of nonliteracy-based messaging in order to reach community members with no formal education.

2. Although they were much more likely to be victims of SGBV, women were significantly less likely than men to be aware of campaigns to end such violence.

Recommendation: Develop and implement targeted approaches for reaching women with SGBV information and campaigns. Such approaches should not only consider women's potentially lower literacy levels, but should also take into account the most effective cultural strategies for reaching women within the culture concerned.

3. Unintended pregnancy due to rape emerged as a key concern in this setting.

Recommendation: Develop and disseminate appropriate Information, Education, and Communication (IEC) messages to de-stigmatize reporting of rape directly to SGBV clinics, or to health facilities in general in the absence of specialized clinics. IEC messages should also emphasize the availability of services and the importance of timely reporting. To complement these exercises, post-rape care must be strengthened to ensure pregnancy prevention services are readily available at health facilities. Psychological support services must also be strengthened to ensure providers are equipped to address the psychological and reproductive health needs of survivors presenting with rape-related pregnancy.

4. Findings suggest that non-partner sexual violence was more likely to be experienced at home by women. The Ugandan policy of providing 1.25 acres of land per household, while commendable and extremely important, also potentially leads to increased vulnerability of women, given that homes are distantly-located from one another.

Recommendation: Re-configure residential arrangements for female-headed households in Ugandan humanitarian settings to ensure enhanced security. For instance, female household heads could reside together on a common piece of land, and still have land left for farming, etc.

5. Findings suggest that care-seeking for sexual IPV was low.

Recommendation: Develop and disseminate appropriate IEC messages to publicize the availability of IPV care. The IEC messages concerned should incorporate issues such as the importance of IPV care (even when injuries do not seem to be severe), and should deal with issues of shame, as these barriers were reasons for low care-seeking behavior among survivors. Building capacity to respond to IPV as a component of post-rape care would also be important. 
Population Council

P.O Box 17643

Nairobi, 00500

Nairobi

Tel: +254 202713480 - 3

Fax: +254202713479

email: info.pcnairobi@popcouncil.org

popcouncil.org

\section{POPUlation COUNCIL \\ Ideas. Evidence. Impact.}
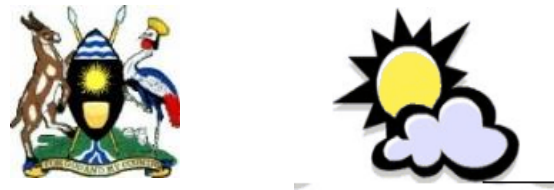